\title{
SUFISM ON THE SILVER SCREEN Indonesian Innovations in Islamic Televangelism ${ }^{1}$
}

\author{
Julia Howell \\ Griffith Asia Institute, \\ Griffith University, Nathan, Queensland, Australia
}

\begin{abstract}
As a carrier of Islam's esoteric tradition, Sufism would seem to be an unlikely candidate for promoting Islamic piety in the popular mass media in Muslim majority societies of the twenty-first century. It is thus remarkable that several of the most sensationally popular of Indonesia's new breed of televangelists have promoted Islam by modelling 'Sufistik' forms of intensified piety. This article examines the electronically-mediated mass predication programs of two of Indonesia's best known televangelists, Abdullah Gymnastiar and M. Arifin Ilham. Both are recognised by the viewing public as 'Sufistik'. The article identifies the elements of the Sufi tradition upon which the preachers draw. It also examines how those elements can be projected effectively on television to convey the intense spiritual intimacy with God which Muslims seek through Sufi devotions.
\end{abstract}

Keywords: Sufism, Islamic piety, popular mass media, Muslim televangelists.

\section{Introduction}

As a carrier of Islam's esoteric tradition, Sufism would seem to be an unlikely candidate for promoting Islamic piety in the popular mass media in Muslim majority societies of the twenty-first century. In the past, guidance on its mystical path was offered only to dedicated initiates by spiritual directors (syekh) who had received from their own

\footnotetext{
1 The author gratefully acknowledges the kind permission of Greg Fealy and Sally White, editors of Expressing Islam: Religious Life and Politics in Indonesia (Singapore: ISEAS Press, 2008) to incorporate parts of her chapter in that volume into this article.
} 
masters the authority to pass on their esoteric knowledge. Moreover, in the twentieth century, all across the Muslim world, Sufism was attacked by Islam's modernist reformers for supposedly being both heretical and anti-modern. It is thus remarkable that two of the most sensationally popular of Indonesia's new breed of twenty-first century televangelists, Abdullah Gymnastiar (popularly known by the familiar appellation 'Aa Gym' or 'Brother Gym') and M. Arifin Ilham, have promoted Islam by modelling 'Sufistik' forms of intensified piety. Aa Gym, who pioneered the new style of high-entertainment value, content-light television preaching in Indonesia, suffered a drastic deflation in his popularity in December 2006 after it became known that he had taken a second wife. Yusuf Mansur, a rising celebrity preacher, quickly took his place at the top of the charts. Interestingly Yusuf Mansur also inserts references to Sufi teachings into his less demanding prosperity-gospel style program for spiritual renewal.

The new breed of Indonesian entertainer-preachers strongly resembles the new-style megastar televangelists like 'Amr Khaled who have emerged in Egypt at the same time. Both the Egyptian and the Indonesian new-style preachers or dai present themselves as 'ordinary', albeit attractively middle-class, Muslims. Thus they disavow any claim to traditional sources of religious authority such as the classical scholarship of the ulama, $\ngtr$ ut glamorously model a 'born again' piety in their entertainment-rich preaching and in the how-to books and DVDs spun off their televised 'Islam lite' preaching. Significantly, however, the Egyptian new-style preachers do not incorporate Sufi themes.

The popularity of Sufi themes in Indonesia, in contrast, is such that they have spread into a new genre of 'Islamic' novel, exemplified by Ayat-Ayat Cinta ('Love Verses') and Laskar Pelangi ('Rainbow Warriors'), and the bloc-buster films based on them. Strong Sufi themes also figure in the songs of several pop singers like Ahmad Dhani, who put out 'Laskar Cinta' ('Warriors of Love') in 2004 and the band Ungu which released 'Para Pencari-Mu' ('Those Who Seek You') in 2007.

In what follows, I examine the electronically-mediated mass predication programs of Abdullah Gymnastiar (Aa Gym) and M. Arifin Ilham, Indonesia's best known 'Sufistik' new-style preachers. Until 2007 both were also the top rating mass-media preachers overall. I identify the elements of the Sufi tradition upon which they have drawn to construct their televised programs and examine how those Sufi 
elements have been projected on the silver screen to convey the intense spiritual intimacy with God which Muslims seek through Sufi devotions.

\section{Sufism in New-Style Islamic Televangelism}

The Sufi tradition famously emphasises God's loving immanence (which we can experience in prayer and read in the signs of His creation) over God's awesome transcendence and wrathful judgments on our infractions of His holy law. The latter is an image familiar in the scripturalist discourse of Sufism's critics, including most Muslim modernists and many classically trained ulama $\boldsymbol{X}_{\mathrm{I}}$ is thus noteworthy that the new-style Egyptian lay televangelists invite their audiences to recommit themselves to scripturalist programs of personal development (emphasising conformity to a selection of traditionalist religious law, or figh) with the inducement of happy personal experiences of the loving God. In the Egyptian context, apparently, this does not invite comparisons with Sufism. There the middle and upper-class fans of the pop-preachers generally associate Sufism with the Sufi syekh and their 'benighted' followers among the rural and urban poor. ${ }^{2}$

In Indonesia, however, Aa Gym and Arifin Ilham, who can be seen as the Asian counterparts of Egyptian 'Amr Khaled, draw on a much fuller palette of Sufi concepts and practices in their on-screen evangelism. This is recognised by both their fans and their detractors: they are popularly identified as 'Sufi' or 'Sufistik'. ${ }^{3}$ Aa Gym has been embarrassed by this, but not Arifin Ilham. What is 'Sufi' about each of these new-style entertainer-preachers will occupy us below. First let us consider the generally unrecognised potential of Sufism, as an esoteric tradition, to be successfully projected through television as an instrument of Islamic revival.

In some ways Sufism is well suited to projecting a model of piety on screen for the modern Muslim, even though it has long been associated with otherworldly withdrawal into the self. To understand

\footnotetext{
${ }^{2}$ M. Gilsenen, Saint and Sufi in Modern Egypt (Oxford: Oxford University Press, 1973), p. 201; V.J. Hoffman, Sufism, Mystics, and Saints in Modern Egypt (Columbia SC.: University of South Carolina Press, 1995), p. 2; Asef Bayat, Making Islam Democratic (Stanford CA.: Stanford University Press, 2007), p. 151.

3 Syaefullah M. Satori, Akhi, Haruskah Manghujat Aa? Jawaban Buku Rapot Merah Aa Gym' (Jakarta: Pustaka Medina, 2003), p. 47.
} 
this it is necessary to appreciate that Sufism need not be equated narrowly with mysticism. Although mysticism, in the sense of the pursuit of ecstatic union with the Divine, is central to the Sufi heritage, the tradition is much broader than this. ${ }^{4}$ Sufi mysticism is under girded by a literature of sophisticated metaphysical speculation, which may be appreciated in its own right for its intellectual insights. Similarly, the fruits of Sufi mystical striving are celebrated and pined after in poetry and music, which may be enjoyed on its own as inspiring literature and as windows opening onto wider spiritual possibilities.

Sufism may also be practiced simply as an ethical discipline. One may thus modestly attempt only the first and second stages of the classic four-fold Sufi path of spiritual perfection (syariat, or mere compliance with the law; and tarekat, or purification of the heart through ethical refinement). These efforts may prepare the way for the lifting of the first veils obscuring the Divine presence. They may, however, be undertaken without higher aspirations for illumination (bakekat) and gnosis (makrifat) (the third and fourth stages of realisation).

Even the potentially ecstatic practices embedded in Sufi zikir ritual (long repetition of short, mantra-like phrases) can be practiced simply to deepen the emotional tone of one's prayers without extending them long enough to induce higher states of rapture. These same zi ikir litanies can also be practiced just as formulae to attract, as it were magically, God's blessings (healing, protection from assault, fertility, etc.).

Clearly there is much more for modern preachers to work within the Sufi tradition than retreat from the world and withdrawal into the inner sanctum of the self and oblivious absorption in gnosis. When we proceed below to examine the Sufi elements in the predication programs of the new-century televangelists Abdullah Gymnastiar (Aa Gym) and Arifin Ilham, we find that three elements of that tradition have proven particularly useful in translating Sufi piety onto the silver screen. First, the theme of closeness to a loving God, which is so prominent in Sufi literature and poetry, has great contemporary appeal and can be projected through emotive voice quality in commentaries

\footnotetext{
${ }^{4}$ William C. Chittick, "Sufism: Sufi Thought and Practice," in The Oxford Encyclopedia of the Modern Muslim World, ed. by John L. Esposito (Oxford: Oxford University Press, 1995), pp. 102-109.
} 
accompanying rituals and in popular styles of religious songs. Second, Sufism's reduplicated litanies (the zikir ritual) can also provide dramatic material for television broadcasts if properly produced. And third, Sufism's ethical project, which is not tied to particular religious laws even though it builds on them in a general way, leaves considerable scope for expansion using the attractively contemporary language of psychology and other social sciences.

\section{Sufi Elements Common to Both Aa Gym's and Arifin Ilham's Ministries}

Aa Gym and Arifin Ilham incorporate practices associated with Sufism into their new-media predication in different ways. Nonetheless there are recognisable Sufi elements common to the ministries of both. Both lead televised mass-audience religious services in which they append to the obligatory prayers certain non-obligatory zikir prayers recommended by Sufi masters. Conventional rikir prayers, which are commonly used in traditionalist Nahdlatul Ulama (NU) circles in everyday practice, may include recitations of some or all of the 99 names of God (asma husna) $\rightarrow$ and brief repetitions of short phrases and passages from the Qur'an (such as the tablistakbir, isti'alah and alFatibah). ${ }^{5}$ In the traditional Sufi orders, the tarekat, where zikir ritual forms part of a mystical path to ecstatic awareness of God, the short phrases are repeated for extended periods, accompanied by movements of the head and upper body and patterned breathing. Neither Aa Gym nor Arifin Ilham leads such potentially ecstatic zilkir, nor do they encourage this practice. However, even without the drama of ecstatic rikir (which can be visually compelling, as we see from the popularity of films of the Mevlevi order's 'whirling' zikir), their services are visually engaging. They do this through scale (massive audiences), the beauty and importance of the settings, and the attendance of celebrities and dignitaries for their major broadcasts.

Aa Gym broke into national television in 2000 with a program called 'Indahnya Kebersamaan' [The Beauty of Togetherness], broadcast monthly by the private television station SCTV from Jakarta's Istiqlal Mosque. Istiqlal, for a time the largest mosque in

\footnotetext{
5 The tabliAs the phrase La ilata ilalla , which expresses Islam's foundational belief in the oneness of God (monotheism); the takbir (Alla akbar) acknowledges God's greatness; the isti'al as ask for God's protection from temptation; and the al-Fab is the seven-line opening passage of the Qur'an.
} 
Southeast Asia, enjoys national pride of place near Indonesia's National Monument. In 2001 Aa Gym received his first invitation to lead an official national commemoration of a religious holiday, also broadcast live on national television from Istiqlal Mosque. This established his reputation as a megastar dai with live audiences of thousands and viewer audiences in the millions.

Arifin Ilham's trademark is the 'great rikir (zikir akbar), the massive services in which he leads audiences of thousands in collective prayers and rikir. The first of these was a Ramadan service in 2001 in the beautiful and monumental At-Tin Mosque attached to the cultural theme park, Taman Mini Indonesia Indah, established in Jakarta by former president Soeharto's wife. Attendance was estimated at 7,000. ${ }^{6}$ Two years later his rikir akbar service to celebrate the Muslim New Year was broadcast to the nation on television from the Istiqlal Mosque.

As foreshadowed above, Aa Gym injects into his services a richly soulful quality through the emotional modulations of his sonorous voice. Arifin Ilham is known for such a voice as well. These vocal and emotional qualities enhance the dramatic quality, and hence the television entertainment value, of the religious services they lead.

The new-style Egyptian lay preachers compensate for their lack of formal learning in the Islamic sciences with a repentance story that is dramatic, but only modestly so, in keeping with the generally Salafist tone of their preaching. In contrast, Indonesian dai Arifin Ilham's story of how his life as a preacher was transformed includes explicitly miraculous events redolent of the world of the Sufis: uncanny survival of a near-fatal snakebite; the gift of a lowered, more beautiful speaking voice bestowed through that crisis; and the revelatory dreams during his convalescence that inspired him to develop his charismatic zikir program.

Aa Gym's life, too, was transformed by dramatic spiritual experiences that helped inspire and legitimise his later role as a dai. While still a youth living in the parental home, his mother and younger sibling, and then Aa Gym himself, dreamed that the Prophet Muhammad was seeking him out. ${ }^{7}$ In Gymnastiar's dream, the Prophet

6 Tb. Ace Hasan Syadzily, Arifin Ilham, Dai Kota Penabur Kedamaian Jiwa Jakarta: Hikmah, 2005), p. 36.

7 Abdullah Gymnastiar, Aa Gym: Apa Adanya, Sebuab Qolbugrafi (Bandung: MQ Publishing, 2003), p. 26ff. 
bade him join in prayers together with the Prophet's close companions, Abu Bakar, Uman, Utsman and Ali. To deal with the intense spiritual yearning that followed, the young Aa Gym sought out a venerable ulama, who recognised that Gymnastiar had received the gift of tanazzul, whereby God had opened his heart to direct knowledge of Him without the necessity of a lengthy process of preparation. This ulama was K.H. Khoer Affandi, well known as a tasawnuf scholar. ${ }^{8}$ Gymnastiar then received special lessons in the Islamic sciences from several ulama without having actually to enrol in a pesantren.

As with Arifin Ilham's extraordinary dreams, Aa Gym's miraculous spiritual experiences link him to the world of the Sufis. Salafi critics have reacted particularly strongly to the stories of his experiences, which contain elements especially offensive to them: meeting the Prophet, and Aa Gym's miraculous religious speed-learning. Thus AlMukaffi, in his inflammatory book Rapot Merah Aa Gym, MQ di Penjara Tasannuf [Aa Gym's Failing Report Card, MQ in the Prison of Sufism], 'takes Aa Gym to task for messing in the world of 'absurd' Sufi esotericism (ilmu ladun ), as evidenced by his claims to uncanny experiences, and explicitly charges him with promoting tasawnuf, which Al-Mukaffi brands as deviation (sesat), heretical innovation (bid'ah) and superstition (kburafat). MQ, he jibes, should really be called 'Majelis Qurafat' (Assembly of the Superstitious). ${ }^{10}$ Aa Gym has denied that he is trying to teach tasawnuf, ${ }^{11}$ but his supporters nonetheless protest that tasammuf is not un-Islamic, citing such revered classical authorities as $\mathrm{Al}$ Ghazali and even Ibn Taymiyya, as well as Indonesia's own champion of Islamic modernism, Hamka. ${ }^{12}$

8 Gymnastiar, Aa Gym, p. 33.

9 Abdurrahman Al-Mukaffi, Rapot Merah Aa Gym: MQ di Penjara Tasawnuf (Jakarta: Darul Falah, 2003).

10 Al-Mukaffi, Rapot Merah Aa Gym. To make the defamatory play on letters, AlMukaffi has actually taken the Arabic word khurafat and rendered it incorrectly but (to some) amusingly into Indonesian orthography as 'Qurafat' to reference the ' $Q$ ' in 'MQ'.

${ }^{11}$ Hernowo and M. Dede Ridwan, Aa Gym dan Fenomena Daarut Taubid (Jakarta: Mizan Pustaka, 2003), p. 49; Satori, Akhi, Haruskah Manghujat Aa?, p. 47.

12 Satori, Akhi, Haruskah Manghujat Aa?, p. 50ff; Tengku Zulkarnain, Salah Faham, Penyakit Umat Islam Masa Kini, Jawaban atas Buku Rapot Merah Aa Gym (Jakarta: Yayasan Al-Hakim, 2003). 
Both Aa Gym and Arifin Ilham also recommend a regimes of daily personal practice that not only add rikir litanies to the obligatory five daily prayers (shalat wajib), but also add an extra set of prayers and litanies, sembabyang sunat tabajud (Ar. tahajjud; night vigil), performed upon waking a few hours after midnight. This type of spiritual regimen is widely used not just in the Sufi orders but in traditionalist Muslim (NU) circles-although it has not been popular in modernist Muslim circles. Nonetheless, aficionados of Aa Gym's and Arifin Ilham's programs come from both modernist and traditionalist family backgrounds. Such family religious affiliations are in any case often attenuated in middle and upper-class homes.

While there are Sufi elements common to the ministries of both Aa Gym and Arifin Ilham, there are also significant differences in the way those elements are deployed on screen as well as off. These can be seen chiefly in the element of entertainment in their public performances, in the way the two preachers use rikir, and in their programs for personal spiritual development.

\section{Arifin Ilham's Sufi Spirituality as Islam Klasik (Salafiyab)}

The trademarks of Arifin Ilham's ministry, 'rikir akbar' and 'rikir taubat' (zikir of repentance), already signal the importance of two of the hallmarks of televangelical Sufism: (1) the element of spectacle that is itself entertaining and attracts television coverage; and (2) the emphasis on sweet repentance, which works to mobilise a highly personal piety focusing on the loving nature of God, not just His punishments. That each of Arifin's trademarks ('rikir akbar' and 'rikir taubat') also explicitly references the pre-eminently Sufi practice of qikir indicates the vein of Islamic heritage into which Arifin's ministry fits. They also suggest how central his renovated program of zikir is to his defensively purist program of Islamic spiritual development, which he has described as 'classic (salafi) Islam' or Islam klasik (salafiyab).13

Zikir was not always a part of Arifin's ministry. It was the miraculous dreams that came to him during his near-fatal illness that inspired him to start including rikir prayers in his already modestly successful lay ministry. He was already a fine orator and had engagements to preach in both Indonesia and abroad even while he was still studying. (He completed a degree in political science from the

${ }_{13}$ M. Arifin Ilham and Syamsul Yakin, Indonesia Berzikir: Risalah Anak Bangsa untuk Negeri Tercinta (Depok: Intuisi Press, 2004), p. 38. 
University of Indonesia.) The dreams convinced him that fine preaching was not enough to meet the spiritual needs of Muslims, particularly in the modern environment where secularism challenges, and consumerism distracts, them. ${ }^{14}$ Like so many Indonesian proponents of a revitalised Sufism, he also thought Islam had become spiritually dry for many people, who were, as a consequence, unable to feel close to God or to work against rampant social problems like corruption and loose morals. ${ }^{15}$ Accordingly, he began to guide people in a carefully constructed program of extended zikir prayers and developed a rationale for the role that the practice of zikir should play in the lives of orthodox Muslims. This program quickly became well known under the name 'rikir taubat.

In contrast to the rikir led by Aa Gym, the rikir Arifin Ilham leads in association with public worship closely follows the standard composition of zikir prayers used by traditionalist Muslims in NU circles: recitation of the 'beautiful' names of God (asmaaul husna); intonation, up to 80 times each, of the tasbih (subhanahu wa taalaf) [and the tabmid (alhamdulillab) (praising God); and repetition of the tablil affirming that there is but one God. ${ }^{16}$ Arifin and those of his associates who have stepped up to defend his use of rikir emphasise that he closely follows those elements of traditional practice for which sanction can be found in the Qur'an and Hadith. These elements are not, they argue against modernist critics, heretical (bid'ab). This concern for orthodoxy is evident in the title of one of Arifin's popular books, Hakikat Zikir, Jalan Taat Menuju Allah [The True Essence of Zikir, the Orthodox (lit. Obedient) Road towards God]. We are to understand that this rikir practice accords with the revealed word of God and the Prophet's example, as illustrated with chapter and verse.

While Arifin has retained in strict form many elements of conventional zikir practice, he has left out others. Those he rejects as bid'ah are practices generally confined to certain Sufi orders: prayers for the intercession of saints (tawassud); taking an initiation (baiat) that binds the student to the master or syekb; visualisation of the initiating master and the masters in his line of initiation (tashawnur); and crediting the

\footnotetext{
14 Achmad Nawawi Mujtaba (ed.), Menggapai Kenikmatan Zikir: Fenomena Mubammad Arifin Ilham dan Majelis Zikir Az-Zikra (Jakarta: Mizan, 2004), p. $147 \mathrm{ff}$.

15 Ilham and Yakin, Indonesia Berzikir, p. 30.

${ }^{16}$ Ilham and Yakin, Indonesia Berzikir, p. 129ff; Syadzily, Arifin Ilham, Dai Kota, p. 96.
} 
syekh with a capacity to bestow esoteric assistance. Each of these practices is regarded as syirik or putting up seconds to God (polytheism). This helps us to understand Arifin's characterisation of his zikir as 'lay zikir' (zikir awam). Not only does this phrase suggest the orthodox idea of the equality of all believers before God, but it valorises a movement (such as his) led by a lay preacher.

If Arifin's program of zikir prayers follows a conventional format, it nonetheless has novel features. Thus, in his zikir Arifin translates each of the beautiful names of God and each new Qur'anic phrase as it comes up for repetitive recitation for his largely non-Arabic-speaking congregation. He explained to Syadzily ${ }^{17}$ that this was so that people could dwell on the meaning of the Arabic phrases, because the recitation of rikir should not just be ceremonial, it should be an 'occasion for self-assessment' (wadah evaluasi diri) and a setting for education (wadah pendidikan). He uses the language of modern psychology to suggest how, when saying the names of God, Muslims should 'internalise' the qualities identified by the holy names, making those qualities part of themselves. ${ }^{18}$

Each of these alterations, however small, can be seen as a significant way of transforming ritual from a mere formula for gaining blessings or a tool for entering an ecstatic state (uses of ritual condemned by Salafi critics of Sufi practice and of traditionalist Islam in general) into a means of finding personal meaning in the life of faith and entering into a directly felt personal relationship with the loving God. In other words, Arifin renders zikir into a path of personal spiritual development in a modern idiom at the same time that he certifies it as an act of strict obedience to the example of the Prophet and his righteous companions given in the earliest and purest days of the faith community.

\section{Abdullah Gymnastiar: Sufi Spiritual Intelligence for Business, School and Family}

Whereas Arifin Ilham carefully renovated Sufi ritual and ethical practice so that he could overtly identify it with tasawmuf and at the same time present it as 'classic Salafi Islam', Aa Gym's ministry is only loosely Sufi inspired and he does not accept Al-Mukaffi's charge that

\footnotetext{
${ }^{17}$ Syadzily, Arifin Ilham, Dai Kota, p. 96.

18 Syadzily, Arifin Ilham, Dai Kota, p. 75.
} 
his famous branded program of personal development, MQ, is faux tasamwnf. Like Arifin, he wants to present Islam in a way that will meet the needs of modern Muslims for a faith that palpably satisfies both their inner need for meaning and spiritual connection as well as their outer, practical need to get along in a challenging world of change. Also, both Arifin Ilham and Aa Gym promote the value of cleansing the heart with Sufi-inspired ethical disciplines for developing professionalism and being a good businessperson, student or parent, but Aa Gym's ministry is much more free-form.

This is evident in Aa Gym's unique manner of dressing, which references the ordinary Indonesian (the sarong), the trendy Asian celebrity (the high-collared jacket), ${ }^{19}$ the pious Muslim sympathetic to Middle Eastern reform currents (the kefiyah), ${ }^{20}$ the young global executive (the slim, sporty figure-or is that a sign of the abstemious man of God?) and the turban ('in the style of a Muslim saint ... seldom copied by other preachers or modern pesantren masters'). ${ }^{21}$ Needless to say, on his handsome person, this manner of dress has great marketing value in the world of commercial television. $\mathrm{He}$ is also a charming singer and jokester and an affable conversationalist. All these talents he deploys in his ministry, working his spiritual development themes into songs like 'Jagalah Hati!' [Tend to Your Heart!], which is almost as well known as his MQ brand, and liberally leavening his sermons, lectures and talk shows with illustrative jokes.

While Aa Gym clearly uses popular forms of entertainment to convey his messages about how to be a good Muslim-pious (takwa), repentant (taubat, istighfar) and capable of exercising initiative (ikbtiar), which by definition is to be a 'success'22 — he objects to any suggestion that he is an entertainer, apparently sensitive to criticism from the public about the younger dai who are hardly distinguishable from artis (singers, actors, comedians and other entertainers). Nonetheless, the entertainment quotient in his preaching is high compared with his predecessors, the professor-preachers. His dress and performance

\footnotetext{
19 A high-collared jacket used to be worn by gentlemen in Java, but now on glossy magazine covers it is more readily associated with the likes of Pakistani cricketer Imran Khan and other South Asian celebrities.

20 The kefiyab is a Middle Eastern style of men's scarf.

${ }^{21}$ Satori, Akhi, Haruskah Manghujat Aa?, p. 7.

22 Satori, Akbi, Haruskah Manghijat Aa?, p. 26.
} 
style also contrast strongly with that of Arifin Ilham, who purposefully adopts simple garb (white kopiah cap and tunic, like many ordinary Indonesian Muslims attending a mosque) and whose preaching is far more sober. Arifin does not joke and sing. His religious services derive their entertainment value primarily from their scale and the melodramatic qualities of his guided reflections in the section of the service devoted to meditation (muraqabab). ${ }^{23}$

Even the prayer section of the religious services led by Aa Gym is more free-form than that led by Arifin Ilham. There is a marked contrast in the way the two preachers lead the rikir. Aa Gym repeats just a few times the phrases from the Qur'an that form the standard components of the rikir and intersperses each set of repeated phrases with long, spontaneous prayers. In these free-form prayers he illustrates the themes of the phrases (the sorts of failings we probably have on our consciences, the things we might be feeling gratitude for at this time). He also projects the emotions appropriate to those reflections through the tenor and pitch of his voice, prompting the famous outpourings of tears for which he (like Arifin Ilham) is famous. These 'riffs' have attracted even more disapproval from the Salafis than the standard repetitions of Qur'anic passages that form the framework of zikir prayers as commonly practised. ${ }^{24}$

Aa Gym's program of personal development, MQ, stretches even further beyond conventional forms of preaching to bring Islam into the world of the modern Muslim. He builds upon the foundational Islamic concepts of cleansing the heart (qolbu) through ethical striving and remembrance of God (zikir), but he explains these in the language of popular psychology and management science. The pre-eminent example of this is the brand name itself. It frames the idea of spiritual cleansing (tarkiya) through ethical discipline as manajemen, and pairs that foreign loan word with the Islamic concept of an esoteric centre (the qolbu or heart) where the intention (niat) that drives discipline is formed. $^{25}$ Aa Gym also draws extensively on psychology and

\footnotetext{
${ }^{23}$ Murapabah is a distinctly but not exclusively Sufi practice of attending to one's inner, spiritual state and setting aside worldly thoughts. In the services led by Aa Gym it is practised collectively in a novel, scripted way with the focus being on moral self-review of one's past behaviour.

${ }^{24}$ Satori, Akbi, Haruskab Manghujat Aa?, p. 88.

25 Abdullah Gymnastiar, Jagalah Hati: Step by Step Manajemen Qolbu (Bandung: Khas MQ, 2005), p. 13.
} 
management literature to fill out a step-wise program suitable for structured group work in a workshop or seminar environment or for individual study. Study questions are provided for students along with concept maps and catchy formulas, for example, his ' $3 \mathrm{M}$ '-Mulai dari diri sendiri (Begin with yourself), Mulailah dari hal yang kecil (Start with small things) and Mulailah dari saat ini (Start right now) —or his '7B', the 'seven secrets for achieving success' (kiat menggapai sukses).

As is apparent from the $3 \mathrm{M}$ or $7 \mathrm{~B}$ formulas, much of the work of personal development recommended in this program is directed towards effective interpersonal relations and effective work habits in everyday life. Thus the tasks associated with Step 3 of the MQ personal development program include 'managing stress', 'managing time', 'routine use of accurate information', 'having the right tools at hand', 'check and re-check', 'being empathetic' and 'communicating and socialising'. Such forms of discipline, we are told, are simultaneously spiritual and practical and have both spiritual and practical benefits. Sufism's ethical project is thus fashionably linked not only to 'this-worldly' betterment but to the popular genres of secular self-improvement books and management science courses drawn from the international market.

\section{Conclusion}

It is evident that the Sufi path of spiritual realisation, which in past times was largely an esoteric tradition directed towards otherworldly experience, can be rendered in distinctly this-worldly and contemporary modalities. Indeed, Indonesia's leading turn- of-thecentury Muslim televangelists, Abdullah Gymnastiar and Arifin Ilham, have substantially reinterpreted Sufism as a framework for living everyday life in the modern world, and the Sufi elements in their preaching have been central to their stellar appeal. In contrast to scripturalist Islam, Sufi Islam foregrounds the loving, merciful attributes of God, rather than God's punishments. It also focuses on God's immanence, rather than His awesome transcendence, and promotes the possibility of experiencing closeness to the loving God in prayer and daily life. This is a religious orientation popular not only in Indonesia but in many traditions across the world today among the world- and self-affirming workforces of late capitalism.

In the hands of Abdullah Gymnastiar and Arifin Ilham, Sufism has proven to be compatible with the new mass media-even with television. Its telegenic features, evident in their programming, include 
the drama of group zikir ritual performed on a grand scale in the setting of magnificent mosques and attended by dignitaries. Sufism's easily dramatised themes of spiritual longing and the responsiveness of an immanent, loving God can also be projected well through the eye of the television camera and its sound system. Thus the 'Sufistik' televangelists use devices like revealing personal stories movingly interjected into congregational zikir ritual, and religiously-themed songs which help convey heightened religious emotion on screen. Furthermore, Sufism's ethical project can be translated effectively into the language of popular psychology and management training and inserted comfortably into talk show programming as well as religious how-to books and DVDs. These have proven attractive especially to middle- and upper-class Indonesian Muslims cognisant of global trends in religious thought and secular culture. [ ]

\section{Bibliography}

Al-Mukaffi, Abdurrahman. Rapot Merah Aa Gym: MQ di Penjara Tasawnuf.Jakarta: Darul Falah, 2003.

Bayat, Asef. Making Islam Democratic. Stanford CA.: Stanford University Press, 2007.

Chittick, William C. "Sufism: Sufi Thought and Practice." in The Oxford Encyclopedia of the Modern Muslim World, ed. by John L. Esposito. Oxford: Oxford University Press, 1995: pp. 102-109.

Gilsenen, M. Saint and Sufi in Modern Egypt. Oxford: Oxford University Press, 1973.

Gymnastiar, Abdullah. Aa Gym: Apa Adanya, Sebuah Qolbugrafi. Bandung: MQ Publishing, 2003.

Gymnastiar, Abdullah. Jagalah Hati: Step by Step Manajemen Qolbu. Bandung: Khas MQ, 2005.

Hernowo and M. Dede Ridwan. Aa Gym dan Fenomena Daarut Taubid. Jakarta: Mizan Pustaka, 2003.

Hoffman, V.J. Sufism, Mystics, and Saints in Modern Egypt. Columbia SC.: University of South Carolina Press, 1995.

Ilham, M. Arifin and Syamsul Yakin. Indonesia Berzikir: Risalab Anak Bangsa untuk. Negeri Tercinta. Depok: Intuisi Press, 2004. 
Mujtaba, Achmad Nawawi (ed.). Menggapai Kenikmatan Zikir: Fenomena Muhammad Arifin Itham dan Majelis Zikir Az-Zikra. Jakarta: Mizan, 2004.

Satori, Syaefullah M. Akhi, Haruskah Manghujat Aa? Jawaban Buku 'Rapot Merah Aa Gym'. Jakarta: Pustaka Medina, 2003.

Syadzily, Tb. Ace Hasan, Arifin Ilham, Dai Kota Penabur Kedamaian Jiwa. Jakarta: Hikmah, 2005.

Zulkarnain, Tengku. Salah Faham, Penyakit Umat Islam Masa Kini Jawaban atas Buku Rapot Merah Aa Gym. Jakarta: Yayasan AlHakim, 2003. 